\title{
PEMBELAJARAN SD/MI BERBASIS SEKOLAH RAMAH ANAK DI MI WAHID HASYIM YOGYAKARTA
}

Syahru Ramadhan dan Yayuk Kusumawati

Email: syahrupgmi05@gmail.com

Institut Agama Islam (IAI) Muhammadiyah Bima

\begin{abstract}
Abstrak
Pelaksanaan pembelajaran SD/MI berbasis sekolah ramah anak menekankan pada aktivitas peserta didik, untuk melakukan berbagai kegiatan yang nyata seperti mengamati dan melihat langsung, mencoba dengan melakukan sendiri tanpa adanya berbagai intimidasi atau tekanan dari pihak lain. Peserta didik dibebaskan untuk berekspresi dan mengemukakan pendapatnya tanpa ada rasa takut. Sehingga peserta didik dapat membentuk pengetahuannya. Seperti halnya pembelajaran yang telah dilaksanakan di MI Wahid Hasyim Yogyakarta. Hasil penelitian ini menunjukan bahwa sekolah ramah anak di MI Wahid Hasyim sudah memenuhi prinsip sekolah ramah anak yaitu nondiskriminasi, kepentingan terbaik bagi anak, kelangsungan dan perkembangan hidup anak, penghormatan terhadap pandangan anak, serta pengelolaan sekolah yang baik. Selain itu pembelajaran SD/MI berbasis sekolah ramah anak tersebut memiliki dampak bagi peserta didik yakni peserta didik dapat lebih berperan aktif dalam proses pembelajaran sehingga peserta didik dapat mengembangkan pengetahuan, sikap dan keterampilannya, disamping itu hak-hak peserta didik dapat terpenuhi.
\end{abstract}

\section{Kata Kunci: Pembelajaran, SD, Ramah Anak}

\section{PENDAHULUAN}

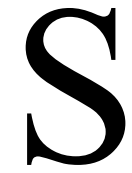

ekolah sebagai salah satu lembaga pendidikan yang mendapat kepercayaan para orang tua yang selama ini dianggap aman, nyaman untuk pengembangan pengetahuan, karakter, dan kepedulian terhadap sesama, nyatanya didalamnya tidak sedikit anak-anak mendapat tekanan fisik maupun non fisik. Berbagai kasus kekerasan dan bulliying terhadap anak-anak akhir-akhir ini muncul di lingkungan sekolah. Berdasarkan survei yang dilakukan oleh KPAI dalam kurun waktu 2011 sampai 2017 bahwa anak rentan menjadi korban kekerasan justru di lingkungan rumah dan sekolah. Artinya lagi, pelaku kekerasan pada anak 
justru lebih banyak berasal dari kalangan yang dekat dengan anak. Lebih lanjut Komisi Nasional Perlindungan Anak mencatat sepanjang tahun 20132014, terjadi peningkatan jumlah kejahatan terhadap anak. Jumlah kejahatan dengan pelaku anak mengalami peningkatan dari 1.121 pengaduan di tahun 2013 menjadi 1.851 pengaduan di tahun 2014 atau meningkat sejumlah 730 kasus. (Profil anak Indonesia, yang diterbitkan oleh kementrian pemberdayaan perempuan dan perlindungan anak bekerjasama dengan pusat statistik, 2015).

Penerapan model sekolah ramah anak pada satuan pendidikan tentu memiliki pengaruh pada desain model pembelajaran. Model pembelajaran yang diterapkan dalam sekolah ramah anak mengacu pada pembelajaran yang ramah juga. Model ini tepat dilaksanakan pada pembelajaran SD/MI. Karena karakteristik anak usia SD/MI masih senang bermain, maka model pembelajaran harus di desain dengan model pembelajaran yang ramah dan menyenangkan. Salah satu model pembelajaran yang diterapkan dalam sekolah ramah anak adalah model pembelajaran aktif inovatif efektif dan menyenangkan. Selain itu model pembelajaran SD/MI berdasarkan kurikulum 2013 harus memuat 3 komponen penting, yaitu: pembelajaran harus merangsang pertumbuhan intelektual dan perkembangan siswa, dengan melibatkan siswa dalam kegiatan praktek/percobaan, dan seharusnya mendorong terbentuknya sikap ilmiah, mengembangkan kemampuan penggunaan keterampilan berfikir kritis, dan rasional (Binti Muakhirin, 2014). Hal ini sesuai dengan tujuan pembelajaran berbasis sekolah ramah anak yaitu membantu siswa mengembangkan kemampuan berfikir tahap tinggi, berpikir kritis dan berpikir kreatif. (Pusat Tenaga Pengembang Pendidikan, 2010).

MI Wahid Hasyim adalah salah satu sekolah di Kota Yogyakarta yang menerapkan model sekolah ramah anak. Sekolah ini ditunjuk sebagai percontohan sekolah ramah anak oleh kementrian pemberdayaan perempuan dan perlindungan anak. (Kepala Sekolah MI Wahid Hasyim 2018). Sekolah ini berupaya menjamin dan memenuhi hak-hak anak dalam setiap aspek 
kehidupan secara terencana dan bertanggung jawab. Programnya lebih mengedepankan kegiatan partisipatif untuk siswa, terutama dalam proses pembelajaran. Hak-hak anak lebih terlindungi dalam kegiatan belajar mengajar di sekolah. Bukan hanya dalam kegiatan pembelajaran, bahkan saat membuat tata tertib kelas pun anak-anak bahkan dilibatkan. Berdasarkan latar belakang di atas maka penelitian ini akan fokus mengkaji lebih mendalam pembelajaran SD/MI berbasis sekolah ramah anak di MI Wahid Hasyim Yogyakarta.

\section{TINJAUAN TEORITIS}

\section{Pembelajaran SD/MI}

Dalam kurikulum 2013 diatur bahwa kurikulum untuk SD/MI menggunakan pendekatan tematik integratif dari kelas 1 sampai kelas VI. Pembelajaran tematik-integratif di SD/MI merupakan pendekatan pembelajaran yang mengintegrasikan berbagai kompetensi dari berbagai mata pelajaran ke dalam berbagai tema. Tujuannya adalah untuk mendorong peserta didik mampu lebih baik dalam melakukan observasi, bertanya, bernalar, dan mengkomunikasikan (mempresentasikan), apa yang mereka peroleh atau mereka ketahui setelah menerima materi pembelajaran. Objek yang menjadi pembelajarannya adalah berkaitan dengan fenomena alam, sosial, seni, dan budaya. Melalui pendekatan tematik-integratif ini diharapkan siswa memiliki kompetensi sikap, keterampilan, dan pengetahuan yang jauh lebih baik (Imam Nur Hakim, 2014).

Pembelajaan tematik adalah pembelajaran terpadu yang menggunakan tema untuk mengaitkan beberapa mata pelajaran sehingga dapat memberikan pengalaman bermakna kepada siswa. Keterpaduan Berdasarkan tema ini, menurut Hartono (2011: 57), akan menghubungkan persoalan satu dengan persoalan lainnya, sehingga terbangunlah kesatuan (unity) pengetahuan. Sebuah pengetahuan yang mempresentasikan kesatuan bagianbagian dengan keseluruhannya (part-whole relationships). Integrasi dalam pembelajaran diharapkan melahirkan pemahaman yang komprehensif pada 
diri peserta didik dan lingkungannya. Hal ini terkait dengan pemahaman bahwa diri manusia adalah bagian dunia yang lebih luas, sehingga peserta didik mampu memahami pengetahuan yang diterimanya melalui kurikulum beserta implementasi dan perkembangannya dalam kehidupan seharihari.

\section{Pembelajaran Konstruktivistik}

Konstruktivistik merupakan salah satu filsafat pengetahuan yang menekankan bahwa pengetahuan merupakan buatan kita sendiri. Pengetahuan bukan tiruan dari realitas, bukan juga gambaran dari dunia kenyataan yang ada. Pengetahuan merupakan hasil dari konstruksi kognitif melalui kegiatan individu dengan membuat struktur, kategori, konsep dan skema yang diperlukan untuk membentuk pengetahuan tersebut (Agus $\mathrm{N}$ Cahyo, 2013). Selain itu Chairul Anwar menjelaskan bahwa pengetahuan tidak bisa ditransfer begitu saja, melainkan harus diinterprestasikan sendiri oleh masing-masing individu. Pengetahuan juga bukan merupakan sesuatu yang sudah ada, melainkan suatu proses yang berkembang terus-menerus. Dalam proses itu, keaktifan seseorang sangat menentukan dalam mengembangkan pengetahuannya. Sebab, pada kenyataannya, masih banyak peserta didik yang salah menangkap sesuatu yang diberikan oleh pendidiknya (Chairul Anwar, 2017). Oleh karena itu, hadirnya kurikulum 2013 adalah untuk mengubah paradigma pembelajaran MI dari pembelajaran yang berpusat kepada guru menuju pembelajaran yang berpusat pada siswa, yaitu dengan siswa membentuk sendiri pengetahuannya. Paradigma ini menuntut guru untuk lebih kreatif dalam mengembangkan pembelajaran dan asesmen otentik, sehingga memungkinkan siswa berekspresi melalui kegiatan-kegiatan nyata yang menyenangkan dan mampu mengembangkan potensi peserta didik secara optimal.

\section{Konsep Sekolah Ramah Anak}

Kristianto menyebutkan bahwa sekolah ramah anak adalah sebuah konsep sekolah yang terbuka, berusaha mengaplikasi pembelajaran yang 
memperhatikan perkembangan psikologis peserta didik. Mengembangkan kebiasaan belajar sesuai dengan kondisi alami dan kejiwaan anak. (Kristanto, 2011). Perhatian dan melindungi anak, lingkungan yang sehat, serta adanya partisipasi orang tua dan masyarakat. Disamping itu, sekolah ramah anak tidak menekan, memaksa, dan mengintimidasi anak sehingga anak memiliki kemerdekaan memilih belajar dan mengembangkan potensinya dengan senang dan riang (Ngadiyo, 2013).

Sekolah Ramah Anak diperkenalkan pada tahun 1999 oleh Bagian Pendidikan Kantor Program UNICEF di New York. Sekolah ramah anak ini didasarkan pada prinsip-prinsip hak-hak anak sebagaimana tertuang dalam konvensi hak anak (1990) dan instrumen Hak Asasi Manusia Internasional dan deklarasi internasional, termasuk deklarasi Pendidikan untuk semua (Mami Hajroh dkk, 2015). Hak anak yang perlu diperhatikan dan dijamin oleh pemerintah sebagaimana tersebut dalam Konvensi Hak anak antara lain hak untuk tempat tinggal, hak untuk mendapatkan keleluasan pribadi, hak untuk mendapatkan rasa aman, hak untuk mendapatkan lingkungan yang sehat, hak untuk bermain, hak untuk mendapatkan pendidikan, dan hak untuk memperoleh transportasi umum (Jazariyah, 2016). Semua anak memiliki hak untuk dilindungi dari kekerasan yang ditimpakan kepadanya oleh siapapun dalam kehidupan mereka-apakah orang tua, guru, teman, pasangan sah atau orang asing (UNICEF, 2017).

Sekolah ramah anak penting dikembangkan pada semua jenjang pendidikan, khususnya jenjang pendidikan sekolah dasar. Karena pada usia ini (6-12) adalah merupakan masa yang pendek tetapi merupakan masa yang sangat penting bagi kehidupan manusia. Menurut Paragito, usia sekolah dasar merupakan masa yang sangat penting bagi penanaman kemandirian dan kecakapan hidup serta nilai-nilai kebaikan (basic goodness) pada individu, karena anak-anak yang berada pada usia ini umumnya masih akan terus tumbuh dan berkembang semua potensi yang dimilikinya dilihat dari aspek psikosial, kognitif dan fisik (Daryanto, 2014). Untuk mewujudkan berkembangnya sebuah model sekolah ramah anak maka ada beberapa hal 
yang harus dipenuhi oleh seluruh elemen yang ada dalam satuan pendidikan. Pertama, suasana sekolah dan kelas yang menyenangkan, kedua, guru harus menguasai kompetensi dasar profesional, ketiga, guru yang menyenangkan, keempat, teman-teman yang baik, kelima, menciptakan iklim yang kondusif di sekolah (Ana Pujiastuti, 2015).

\section{METODOLOGI PENELITIAN}

Penelitian ini bertujuan untuk mendiskripsikan secara umum sekolah ramah anak dan juga model pembelajaran di SD/MI di MI Wahid Hasyim Yogyakarta. Penelitian ini menggunakan pendekatan kualitatif dengan jenis penelitian studi kasus. Metode pengumpulan data dengan wawancara, observasi, dan dokumentasi (Jhon Creswell, 2014). Adapun sumber informan dalam penelitian ini adalah kepala sekolah, guru, orang tua siswa, dan siswa.

\section{HASIL TEMUAN PENELITIAN}

Sekolah ramah anak adalah suatu program yang dalam pelaksanaanya menjadikan kepentingan dan kebutuhan peserta didik sebagai pertimbangan utama dalam menetapkan setiap keputusan dan tindakan yang diambil oleh pengelola dan penyelenggara pendidikan. Sekolah ramah anak dilatar belakangi oleh beberapa hal, seperti maraknya kasus kekerasan yang terjadi pada anak di lingkungan sekolah, baik yang dilakukan oleh guru maupun oleh peserta didik khususnya di wilayah Dearah Istimewa Yogyakarta, setiap tahun kasus kekerasan yang terjadi pada peserta didik di lingkungan sekolah semakin meningkat (Nisfi Anisah, 2018). Selain itu sekolah ramah anak dilatar belakangi oleh sistem pembelajaran yang masih menggap peserta didik sebagai objek pendidikan bukan sebagai subjek pendidikan, dan menjadikan pusat pembelajaran pada guru, dan biasanya memandang peserta didik seperti bejana kosong yang siap diisi. Sehingga dengan adanya anggapan tersebut maka guru akan selalu menjadi pihak yang paling benar yang tidak bisa disalahkan oleh siswa. Sebagaimana diaungkapkan oleh guru berikit ini: 
“... karena kebanyakan di sekolah-sekolah siswa cenderung menjadi objek dan guru menjadi pihak yang paling benar, tetapi kami disini tidak menggunakan model pembelajaran tersebut, kami menerapkan model pembelajaran dengan menyenangkan siswa, selain itu, beberapa tahun terakhir ini kota yogyakarta banyak terjadi kasus kekerasan di dunia pendidikan maka pemerintah kota yogyakarta merancang adanya sekolah ramah anak".

Dari pendapat tersebut dapat diungkapkan bahwa praktik dalam dunia pendidikan masih menganggap guru menjadi pihak yang paling benar, dan siswa menjadi objek pendidikan, selain itu maraknya kasus kekerasan yang terjadi dalam dunia pendidikan akan mengakibatkan dampak yang tidak baik terhadap perkembangan pengetahuan, sikap dan keterampilan siswa. Padahal pencapaian kompetensi yang diharapkan pada kurikulum 2013 adalah kompetensi utuh yang saling terkait meliputi kompetensi pengetahuan, sikap dan keterampilan siswa yang tertuang dalam KI 1, KI 2, KI 3, dan KI 4. Fenomena diatas menjadi alasan MI Wahid Hasyim Yogyakarta untuk mewujudkan sekolah ramah anak. Komitmen ini didukung oleh Dinas Pemberdayaan Perempuan dan Perlindungan Anak (DP3A) dengan dikeluarkannya SK Walikota Yogyakarta yang menetapkan MI Wahid Hasyim Yogyakarta sebagai salah satu model percontohan sekolah ramah anak. Sebagaimana yang diungkapkan oleh Kepala Sekolah MI Wahid Hasyim Yogyakarta (Fajar Dwi Mukti, 2018) sebagai berikut.

“... sebenarnya sebelum di keluarkan SK oleh Walikota kami sudah menerapkan sekolah ramah anak, akan tetapi secara resminya program sekolah ramah anak ini berjalan setelah ada SK yang dikeluarkan dari walikota, sebagai ditunjuk sebagai percontohan sekolah ramah anak di Yogyakarta, karena kota yogyakarta akan digagas sebagai kota layak anak".

Sekolah ramah anak adalah sekolah yang menjunjung tinggi hak-hak anak. Semua anak berhak untuk mendapat perlindungan dari semua ancaman kekerasan baik itu dilingkungan tempat tinggal anak maupun di lingkungan sekolah. Pelaksanaan sekolah ramah anak di MI Wahid Hasyim Yogyakarta adalah salah satu bentuk dari komitmen para pelaku pendidikan di MI Wahid Hasyim untuk mewujudkan sekolah ramah bagi anak, yaitu 
sebuah sekolah yang menghargai hak-hak dan melindungi anak agar anak merasa betah dan nyaman di sekolah.

\section{Penerapan Pembelajaran MI Berbasis Sekolah Ramah Anak}

Sekolah ramah anak dapat diimplementasikan melalui pembelajaran yang berkualitas. Dengan demikian pembelajaran inovatif yang mampu memberikan layanan kepada peserta didik guna berkembang potensinya merupakan keharusan dalam sekolah ramah anak. Pembelajaran yang inovatif tersebut sudah seharusnya memfasilitasi peserta didik mengembangkan potensinya dan membantunya mencapai tugas-tugas perkembangannya, sikap dan perilaku seorang pembimbing, menerima dan memahami kondisi siswa, mampu menciptakan iklim interaksi dengan anak yang harmonis. Dalam hal ini, peserta didik dilibatkan dalam berbagai aktivitas yang dapat mengembangkan kemampuannya. Siswa diberi kesempatan untuk menyampaikan gagasannya, memajangkan hasil karyanya, diikutsertakan dalam pemeliharaan fasilitas sekolah.

Pembelajaran di MI Wahid Hasyim mengacu pada model pembelajaran PAIKEM yang berbasis student center dengan pendekatan saintifik sesuai dengan karakteristik pendekatan pembelajaran dalam kurikulum 2013. PAIKEM adalah sebuah model pembelajaran yang diterapkan di sekolah ramah anak, yang bertujuan untuk melibatkan partisipasi peserta didik secara aktif, dan proses pembelajaran berlangsung dengan menyenangkan. Sehingga dalam setiap proses pembelajaran, guru mendesain model belajar dengan menyertakan unsur permainan dalam setiap pelajaran. Karena salah satu cara untuk menjamin terpenuhnya hak anak di sekolah ramah anak adalah peserta didik memperoleh pendidikan sesuai dengan tugas perkembangannya.

Kegiatan pembelajaran yang dilakukan oleh masing-masing guru di MI Wahid Hasyim Yogyakarta tidak sama. Hal ini dikarenakan guru melhat masing-masing kondisi kelas dan karakteristik pembelajaran yang akan disajikan dalam satu kali pertemuan. Untuk mengetahui strategi yang digunakan oleh guru pada waktu melakukan proses pembelajaran peneliti 
melakukan wawancara terlebih dahulu dengan Bapak Fajar Dwi Mukti selaku Kepala Sekolah MI Wahid Hasyim dan beliau menyampaikan sebagai berikut :

“.. kalau kami disini menggunakan model pembelajaran PAIKEM, dengan strategi tutor sebaya, diskusi kelompok, imquiry dan CTL dan lainnya yang menyesuaikan dengan karakteristik tiap muatan pembelajaran dan tujuan pembelajaran yang ingin dicapai".

Salah satu indikator sekolah ramah anak adalah terpenuhinya kebutuhan dan hak-hak anak dalam pendidikan. Oleh karena itu disekolah ramah anak diperlukan pendidik dan tenaga pendidikan yang terlatih hakhak anak. Untuk mewujudkan hal tersebut, maka dilakukan sosialisai sekolah ramah anak. Dalam sosialisasi tersebut tentu para penddik dan tenaga pendidikan diberikan wawasan mengenai pemenuhan hak-hak anak dalam dunia pendidikan melalui sekolah ramah anak (Fajar Dwi Mukti, 2018).

Adapun keterkaitan antara pembelajaran di SD/MI dengan sekolah ramah anak adalah pada prinsip partisipasi, yaitu peserta didik dberikan kesempatan untuk terlibat aktif dalam proses pembelajaran seperti terlihat dalam kegiatan pembelajaran yaitu siswa diajak untuk berdiskusi, melakukan percobaan, mengamati, mengemukakan pendapat, dan bebes berekspresi tanpa ada tekanan dari pihak lain atau dalam sekolah ramah anak disebut dengan prinsip proteksi. Prinsip proteksi ini menekankan pada pemenuhan rasa aman kepada peserta didik juga memberikan pengaruh pada proses pembelajaran. Anak yang hidup dalam suasana aman akan menumbuhkan keberanian untuk belajar, berkreasi, bertanya, bereksplorasi, melalui percobaan, pengamatan dan lain-lain.

\section{Prinsip Sekolah Ramah Anak di SDIT MI Wahid Hasyim Yogyakarta}

Pelaksanaan sekolah ramah anak harus memperhatikan prinsip-prinsip sekolah ramah anak, untuk menjamin terpenuhinya kebutuhan dan hak-hak anak dalam pendidikan. Ada beberapa prinsip sekolah ramah anak yang dilaksanakan di MI Wahid Hasyim Yogyakarta: 


\section{a. Nondiskriminasi}

Prinsip nondiskriminasi dilaksanakan dengan tidak memberikan perlakuan yang berbeda terhadap peserta didik, baik dari suku , agama, gender, maupun ras. Sebagaimana dalam pasal 4 UU No. 23 tahun 2002 tentang perlindungan anak, menyebutkan bahwa anak mempunyai hak untuk dapat hidup tumbuh, berkembang dan berpartisipasi secara wajar sesuai harkat dan martabat kemanusiaan, serta mendapatkan perlindungan dari kekerasan dan diskriminasi. Prinsip nondiskriminasi yang dilaksanakan di MI Wahid Hasyim Yogyakarta ialah setiap anak dilindungi dari segala perlakuan diskriminasi baik dari suku, agama, ras, golongan, jenis kelamin, etnik, budaya dan bahasa, status hukum anak, urutan kelahiran anak dan kondisi fisik atau mental. Seperti halnya yang diungkapkan oleh Ibu Ranti Safi'ah Selaku Wali Kelas V di MI Wahid Hasyim sebagai berikut:

“... dengan menghormati keberagaman ini dengan cara tidak membedakan dan memprioritaskan siswa berdasarkan kemampuannya, maksudnya misalnya anak yang paling pintar matematika lebih disayang atau gimanalah. Kami disini tidak membeda-bedakan siswa apalagi berdasarkan suku dan agamanya”.

Hasil wawancara diatas menegaskan bahwa di MI Wahid Hasyim Yogyakarta tidak membedakan perlakuan terhadap peserta didik. Baik peserta didik laki-laki dan perempuan, cerdas-lemah, kaya-miskin, normalcacat, anak pejabat-anak buruh, dan tidak pula membedakan perlakuan berdasarkan agama, maupun struktur sosial dan budaya setempat. Saling menghormati hak-hak baik antara peserta didik, guru maupun antara tenaga kependidikan lainnya (Ranti Safiah, 2018).

b. Kepentingan terbaik bagi anak

Kepentingan terbaik bagi anak yaitu senantiasa menjadi pertimbangan dalam membentuk suatu keputusan atau program. Prinsip ini terlihat dengan banyaknya kegiatan ekstrakurikuler yang dapat membantu mengembangkan potensi peserta didik. Peserta didik dibebaskan untuk memilih kegiatan 
ekstrakurikuler yang mereka minati (Hasil Observasi). Ada beberapa kegiatan ekstrakurikuler di MI Wahid Hasyim Yogyakarta seperti, drumband, polisi cilik, qasidah, seni, (Batik, kaligrafi, dan lukis) seni tari, seni sastra dan drama, TIK, bimbingan olimpiade, english club, voly mini, paduan suara, pramuka, pengolahan sampah dan lain-lain.

Kegiatan tersebut diatas penting untuk dikembangkan karena dapat mendukung perkembangan potensi, bakat yang sesuai dengan minat peserta didik. Peserta didik diberikan kebebasan berpendapat dan memilih ekstrakurikuler yang akan diikuti sesuai dengan bakat dan minat. Selain itu guru memberikan contoh untuk tidak melakukan tindakan fisik kepada siswa yang melakukan pelanggaran. Apabila siswa melakukan pelanggaran guru cukup menasehati dan memberikan peringatan lisan. Selain menyiapkan beberapa kegiatan ekstrakurikuler, MI Wahid Hasyim menyediakan bahan bacaan yang refresentatif di perpustakaan. Hal tersebut dilakukan untuk mengakomodasi kebutuhan anak dalam membaca. Selain itu membuat program pojok baca untuk meningkatkan literasi anak, dan membuat sarana tempat diskusi peserta didik. Dengan adanya upaya menyediakan berbagai kebutuhan dalam pengembangan bakat, minat dan potensi peserta didik, dengan pertimbangan kepentingan terbaik bagi peserta didik, maka hak-hak anak dapat terpenuhi di lingkungan sekolah.

c. Kelangsungan dan perkembangan anak

Salah satu prinsip penting dalam pengembangan sekolah ramah anak yaitu menjamin keberlangsungan hidup peserta didik dengan memperhatikan perkembangan anak. Prinsip ini telah dilihat di MI Wahid Hasyim Yogyakarta karena tidak lagi memmakai hukum fisik, dan menghindari adanya perilaku bullying di sekolah baik itu bullying yang dilakukan oleh guru, maupun sesama peserta didik. Berdasarkan pengamatan peneliti, guru di MI Wahid Hasyim Yogyakarta selalu mengingatkan kepada semua peserta didik untuk tidak saling mengejek dan membully satu sama lain. Seperti halnya yang telah disampaikan oleh kepala MI Wahid Hasyim Yogyakarta sebagai berikut: 
"guru selalu memberi pujian pada perilaku positif siswa kalau ada siswa yang perilakunya kurang baik hukumannya diberikan sesuai kesepakatan antara guru dan siswa, dan tidak ada lagi penerapan hukum fisik di kelas".

Hal ini juga diungkapkan oleh bapak Nazri Adlani selaku guru di MI Wahid Hasyim (Nazri Adlani, 2018) sebagai berikut:

"kami tidak pernah melakukan hukuman fisik, hanya saja kami memberikan ikrar kepada siswa untuk tidak melakukan lagi kesalahannya, dan meminta orang tua bekerja sama terkait masalah tersebut jika diulangi lagi, contohnya jika tidak disiplin kalau dikelas saya, saya membuat kesepakatan memberi sanksi kepada siswa yang tidak disiplin dan memberi reward bagi siswa yang menjadi teladan kedisiplinan, sanksinya bisa macam-macam sesuai dengan kesepakatan kita”.

Hasil wawancara diatas menegaskan bahwa prinsip ketiga tersebut sudah dilaksanakan dengan cukup baik. Prinsip tersebut penting untuk diaplikasikan di sekolah khususnya di sekolah yang berkeinginan untuk mewujudkan sekolah ramah anak. Karena adanya perilaku bullying dan memberikan hukuman fisik maupun nonfisik bisa menyebabkan peserta didik trauma untuk hadir dikelas.

d. Penghormatan terhadap pandangan anak

Penghormatan terhadap anak yaitu mencakup perhormatan atas hak anak untuk mengekspresikan pandangan dalam segala hal. Prinsip tersebut dapat dilaksanakan dengan berbagai cara, salah satunya menurut guru di MI Wahid Hasyim Yogyakarta adalah menghargai pendapat anak, dan melatih anak untuk berani memberi pendapat dan mampu mengekspresikan pendapat mereka tanpa ada intimidasi dari pihak lain. Seperti hasil pengamatan peneliti, salah satu peserta memberi usul kepada guru dalam hal pembagian kelompok diskusi. Peserta didik tersebut mengusulkan dalam pembagian kelompok tidak boleh memilih-milih teman yang sama-sama pintar, dan guru kelas menyambut baik usul itu. Selain itu berdasarkan hasil wawancara dengan bapak Nazri Adlani di MI Wahid Hasyim Yogyakarta sebagai berikut : 
"...misalnya dalam berdiskusi siswa berpendapat, siswa lain diajarkan menghargai pendapat temannya".

Dari hasil wawancara dan pengamatan tersebut dapat dikatakan bahwa pelaksanaan sekolah ramah anak di MI Wahid Hasyim Yogyakarta sudah memperhatikan prinsip penghormatan terhadap pandangan anak. Penghargaan terhadap pendapat anak adalah penghormatan atas hak-hak anak untuk berpartisipasi dan menyatakan pendapatnya dalam pengambilan keputusan terutama jika menyangkut hal-hal yang mempengaruhi kehidupannya. Penghormatan terhadap pandangan dan pendapat peserta didik disekolah dapat dilaksanakan dengan tidak mencemooh pendapatnya. Guru dapat mengapresiasi pendapat peserta didik dengan cara mendengarkan pendapat peserta didik, memberikan respon positif, dan juga memberikan kesempatan peserta didik untuk memajang hasil karyanya di mading kelas.

e. Pengelolaan yang baik

Prinsip pengelolaan yang baik dapat dilihat dari transparansi berbagai informasi tentang sekolah, dan partisipasi dari berbagai pihak dalam mewujudkan sekolah ramah anak. Hal ini diungkapkan oleh kepala sekolah MI Wahid Hasyim Yogyakarta (Fajar Dwi Mukti, 2018) sebagai berikut:

"dalam pengelolaan sekolah ramah anak ini kami selalu memberikan motivasi ketika komitmen mereka kendor, memperhatikan kesejahteraan para guru dan pegawai, dan tentunya membangun dan memperluas jaringan kerja sama dan tentunya mengadakan pelatihan kepada guru-guru dan warga sekolah lainnya terkait dengan sekolah ramah anak ini".

Pelaksanaan sekolah ramah anak dilakukan bukan hanya memperlakukan anak secara ramah tetapi juga memberikan apa yang menjadi kebutuhan anak. Kebutuhan anak yang dimaksud adalah kebutuhan anak dalam pengembangan diri melalui pendidikan di lingkungan sekolah, baik pengembangan bakat, minat, maupun pengembangan karakter anak. Selain itu sekolah harus memenuhi kebutuhan anak melalui sarana dan prasarana dan memberikan pelayanan yang baik dalam pembelajaran. Anak juga harus diberi kebebasan dalam berekspresi dan berpendapat. 


\section{SIMPULAN}

Pembelajaran SD/MI berbasis sekolah ramah anak di MI Wahid Hasyim Yogyakarta dapat dilihat dari beberapa pemenuhan prinsip sekolah ramah anak yaitu nondiskriminasi, kepentingan terbaik bagi anak kelangsungan hidup, dan perkembangan, penghormatan terhadap pandangan anak, pengelolaan yang baik. Selain itu implementasi sekolah ramah anak di MI Wahid Hasyim memperhatikan beberapa komponen yang dijadikan indicator sekolah ramah anak, seperti komitmen tertulis yang memuat kebijakan sekolah ramah anak salah satunya dengan adanya pelarangan hukuman fisik bagi siswa, pelaksanaan pembelajaran yang ramah seperti proses pembelajaran dilakukan dengan menyenangkan dan tidak bias gender, pendidikan dan tenaga kependidikan terlatih hak-hak anak komponen ini diwujudkan dengan adanya sosialisasi tentang sekolah ramah anak yang membahas hak-hak anak kepada guru dan warga sekolah lainnya.

\section{DAFTAR PUSTAKA}

Anwar Khairul. 2017. Teori-teori Pendidikan Klasik Hingga Kontemporer, Yogyakarta, IRCiSoD.

Agus N Cahyo. 2013. Panduan Aplikasi Teori-teori Belajar Mengajar Teraktual dan Terpopuler, Yogyakarta, DIVA Press.

Ana Pujiastuti. 2015. Pendidikan Yang Menyenangkan: Guru, Sekolah dan Perpustakaan, Yogyakarta, Lembaga Ladang Kata.

Daryanto. 2014. Pembelajaran Tematik, Trpadu, Terintegrasi Kurikulum 2013, Yogyakarta, Gava Media.

Fajar Dwi Mukti. 2018. Wawancara Dengan Kepala Sekolah MI Wahid Hasyim Yogyakarta.

Creswell, J. W. 2014. Penelitian Kualitatif dan Desain Riset, Memilih Diantara Lima Pendekatan, Yogyakarta, Pustaka Pelajar.

Kristanto. 2011. "Identifikasi Model Sekolah Ramah Anak Jenjang Satuan Pendidikan Anak Usia Dini Se-Kecamatan Semarang Selatan" Dalam Jurnal Penelitian PAUD. Volume 1 no. 1 e-jurnal 2011. Diakses dilaman ikippgri.ac.id.

Mami Hajroh. 2015. "Pengembangan Sekolah Ramah Anak di Kawasan Pesisir Daerah Istimewa Yogyakarta" Dalam Laporan Hasil Penelitian DIPA, Kementrian Riset dan Teknologi, Pendidikan Tinggi Universitas Negeri Yogyakarta. 
Nazri Adlani. 2018. Wawancara Dengan Guru MI Wahid Hasyim Yogyakarta.

Nisfi Anisah. 2018. Wawancara Dengan Guru MI Wahid Hasyim Yogyakarta.

Ngadiyo. 2013. Homescooling, Melanjutkan Potensi Anak. Dalam Jurnal Majalah Embun. Edisi 49-V-Rajab 1434 H/Mei.

Ranti Safi'ah. 2018. Wawancara Dengan Wali Kelas V MI Wahid Hasyim Yogyakrta. 